This item was submitted to Loughborough's Research Repository by the author.

Items in Figshare are protected by copyright, with all rights reserved, unless otherwise indicated.

\title{
Tariffs, horizontal regulatory standards and protection against foreign
} competition

PLEASE CITE THE PUBLISHED VERSION

http://dx.doi.org/10.2202/1524-5861.1456

PUBLISHER

(c) De Gruyter

VERSION

AM (Accepted Manuscript)

LICENCE

CC BY-NC-ND 4.0

REPOSITORY RECORD

Edwards, T. Huw. 2019. "Tariffs, Horizontal Regulatory Standards and Protection Against Foreign Competition”. figshare. https://hdl.handle.net/2134/14642. 
This item was submitted to Loughborough's Institutional Repository (https://dspace.lboro.ac.uk/) by the author and is made available under the following Creative Commons Licence conditions.

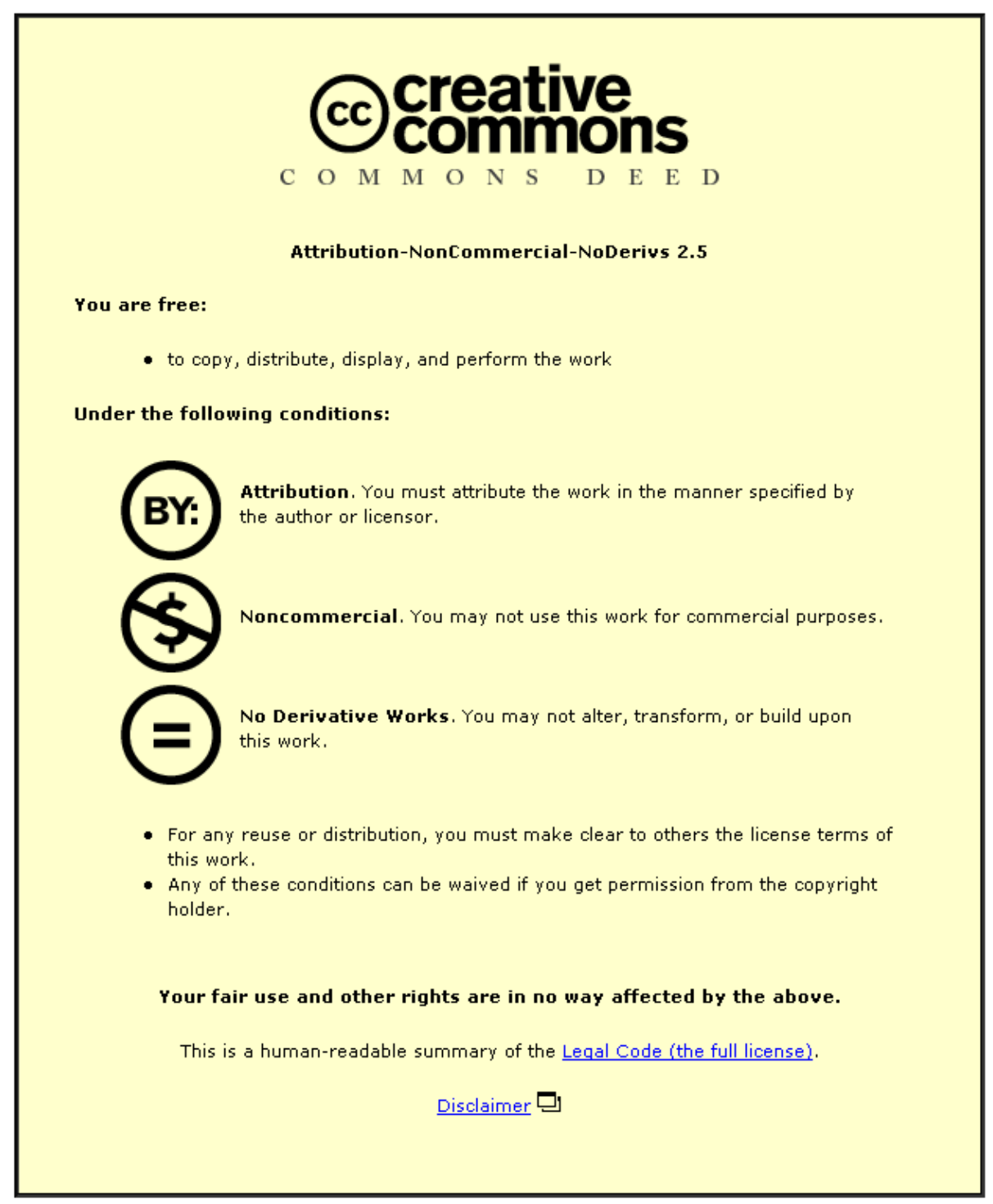

For the full text of this licence, please go to: http://creativecommons.org/licenses/by-nc-nd/2.5/ 


\title{
International Share Ownership, Profit Shifting and Protectionism.
}

\author{
T.Huw Edwards, Department of Economics, \\ Loughborough University, UK, and IfW, Kiel, Germany.*
}

October 28, 2008

I examine the implications of increasing stock market globalisation for the economics of protection. European, Japanese and Australian data mostly indicate that over 30 per cent of the stock market is now foreign-owned, a large increase on the 1980s. Foreign share ownership in the USA is lower, but increasing fast. This degree of foreign share-ownership is likely to change qualitatively the nature of governmental support for 'domestic' firms. A series of worked duopoly examples suggests that the level of foreign share-ownership is usually sufficient for profit-shifting on its own no longer to justify protection .

JEL Classifications: F10, F12.

\section{Introduction}

In this paper, I examine the implications of increasing globalisation of share ownership on the economics of protection. In particular, I examine the argument traditionally made for such protection on the basis of a profit-shifting motive. If proper account is taken of the foreign ownership share of national

*Thanks to Daniel Gros, Rafael Plata, Joanna Poyago-Theotoky, Ben Ferrett and Vasileios Zikos for advice and suggestions, as well as to an anonymous referee. Any errors are my own. 
champions, the profit-shifting arguments in favour of protecting such firms are greatly reduced. Current data on European stock exchanges indicate that over 30 per cent of the stock market is foreign-owned in the majority of countries, a large increase on a couple of decades ago.

The issue which I address is whether this degree of foreign share-ownership is likely to change qualitatively the nature of the response of governments to FDI and support for 'domestic' firms. In particular, I use a series of worked examples, based upon duopoly theory using both linear and isoelastic demand specifications. In most cases, the level of foreign share-ownership is now sufficient to render protection unattractive.

\section{Profit shifting and protection}

Much of the literature on strategic trade policy is reviewed in BRANDER [1995]. Models such as the BRANDER AND SPENCER [1985] or EATON AND GROSSMAN [1986] assume that one firm in a duopoly is domesticallyowned, while the other is foreign owned. The government therefore has an incentive to intervene, via subsidies or other policies, to favour its own national company. The key motive is profit-shifting: if a market is imperfectly competitive, then firms will charge a profit markup $\mu$ over marginal cost, where $\mu$ is typically expected to be $1 /((\varepsilon / \alpha)-1)$, where $\varepsilon$ is the demand elasticity and $\alpha$ is its market share. Therefore, if marginal costs are constant, profits will account for proportion $\mu /(1+\mu)$ of total turnover. A policy such as a tariff or quota or subsidy, or the use of regulations to keep a foreign entrant out, would be expected to worsen consumer welfare: however, if the share of profits in output, $\mu /(1+\mu)$, is sufficiently large, and if the policy raises the domestic firms' share of those profits by a sufficient amount, then the policy may benefit national welfare at the margin (at the expense of foreigners). Profit-shifting is frequently cited as a motivation for the government intervention in a number of industries, such as civil aircraft manufacturing (PAVCNIK [2002])..

The impact of foreign share ownership on these profit-shifting duopoly models ${ }^{1}$ was examined in a series of papers around 1990. LEE [1990] examines in theoretical terms a Cournot setup in a two-country world, where only

\footnotetext{
${ }^{1}$ The great majority of studies of profit-shifting have concentrated on duopoly, probably because the impact of profit-shifting on policy is likely to be greater in the presence of just two competing firms, rather than more firms, where profits will be lower.
} 
one country (1) consumes the good in question. A home firm based in country 1 competes with imports from a rival in country 2. An increase in the proportion of the firm in country 2 owned by inhabitants of 1 and vice-versa is shown to lower the optimal export subsidy and import tariff at the same rate. He then derives the critical values of home share-ownership and ownership abroad where export subsidies and/or import taxes become negative. These values are fairly specific to the case where there are just two countries in the World: in practice, many shares may be owned by third-party nationals.

DICK [1993] examines a model, following BRANDER AND SPENCER [1985], where two firms of different nationality compete in a third country's market. Again this is examined in the context of Cournot competition with a linear demand function. On data for the United States from the US Department of Commerce [1990], where an average of $14 \%$ of US industry was owned by foreigners ${ }^{2}$, while $3.36 \%$ of non-US industry was owned by Americans, he estimated that the average optimal export subsidy would be reduced by $47 \%$ relative to the Brander-Spencer value.

In this paper, I suggest that even Dick's [1993] paper underestimates the difference international share ownership would make in many countries today. This is both because many countries have far more internationalised equity markets than the United States, and also because the degree of international share-ownership has grown hugely over the last 15 years. In the classic linear Cournot setup of two firms competing for a third-country market, international share-ownership in most cases now exceeds the critical levels where any (nonnegative) level of export subsidy is optimal. I then extend this analysis to the isoelastic demand version of the model, where threshold values have not previously been derived, and look in more detail at scenarios of protection in an importing country. In particular, I go beyond tariff-setting (which is often ruled out in practice by international agreements), and look at regulatory protection and the exclusion of foreign competitors to national champions. In all these scenarios, I find a significant effect of international share-ownership: in most cases, profit-shifting is unlikely to be sufficient to justify protectionism.

\footnotetext{
${ }^{2}$ These estimates were based upon FDI data for 1986. Much of the portfolio ownership of stock markets covered in the FESE (Federation of European Stock Exchanges) data is additional to direct ownership of domestic firms by foreigners, and so, in one sense, FDIbased numbers are almost certainly an underestimate of the true extent of international equity ownership.
} 
It should be noted that there are other possible reasons for protecting a domestic firm, apart from profit-shifting. These include exploitation of static and dynamic scale economies or spillovers, distributional factors, the desirability of maintaining domestic head-office capability, the supposed greater accountability of local firms to local regulators etc. Nevertheless, I largely concentrate in this paper on cases where profit shifting is the primary motive for protection.

\section{Internationalisation of Share Ownership}

A key feature of the early papers on profit-shifting (i.e. prior to LEE [1990]) is that firms can easily be classified according to their 'nationality': in other words, they assume $100 \%$ of shares in the domestic firm(s) are owned by domestic nationals, and $100 \%$ of shares in foreign firms are owned by foreigners. While this may be the case when a firm is nationalised, or where it is a private or family-owned company, it is unlikely to be the case with most public limited companies (see recent papers by EDWARDS AND GROS [2006] and VERON [2006] on the demise of European national champions).. We can split shares into those owned directly by the state (proportion $s$ ), those directly owned by foreigners, proportion $\theta$, those owned by other firms and financial institutions based in the domestic country quoted on the stock market, proportion $m$ and those directly owned by pension funds and the like, proportion $p=1-s-\theta-m$. If the rate of corporate taxation is $t$, then a lower bound estimate for the share of profits of domestically-based companies (net of tax) which actually ends up accruing to foreigners is

$$
\phi_{L}=\theta
$$

However, if many of the other firms and financial institutions who own shares within the country are themselves partly foreign-owned, then a higher estimate of the proportion of profits which actually ends up in companies' hands is the solution to a geometric progression, which yields:

$$
\phi_{H}=\theta /(1-m) \text {. }
$$

Taking the examples of Germany, France, the UK and Italy in 2003 the structure of share ownership, as quoted by FESE, is shown in Appendix Table 1. In the case of Italy, our lower-bound estimate for foreign ownership 


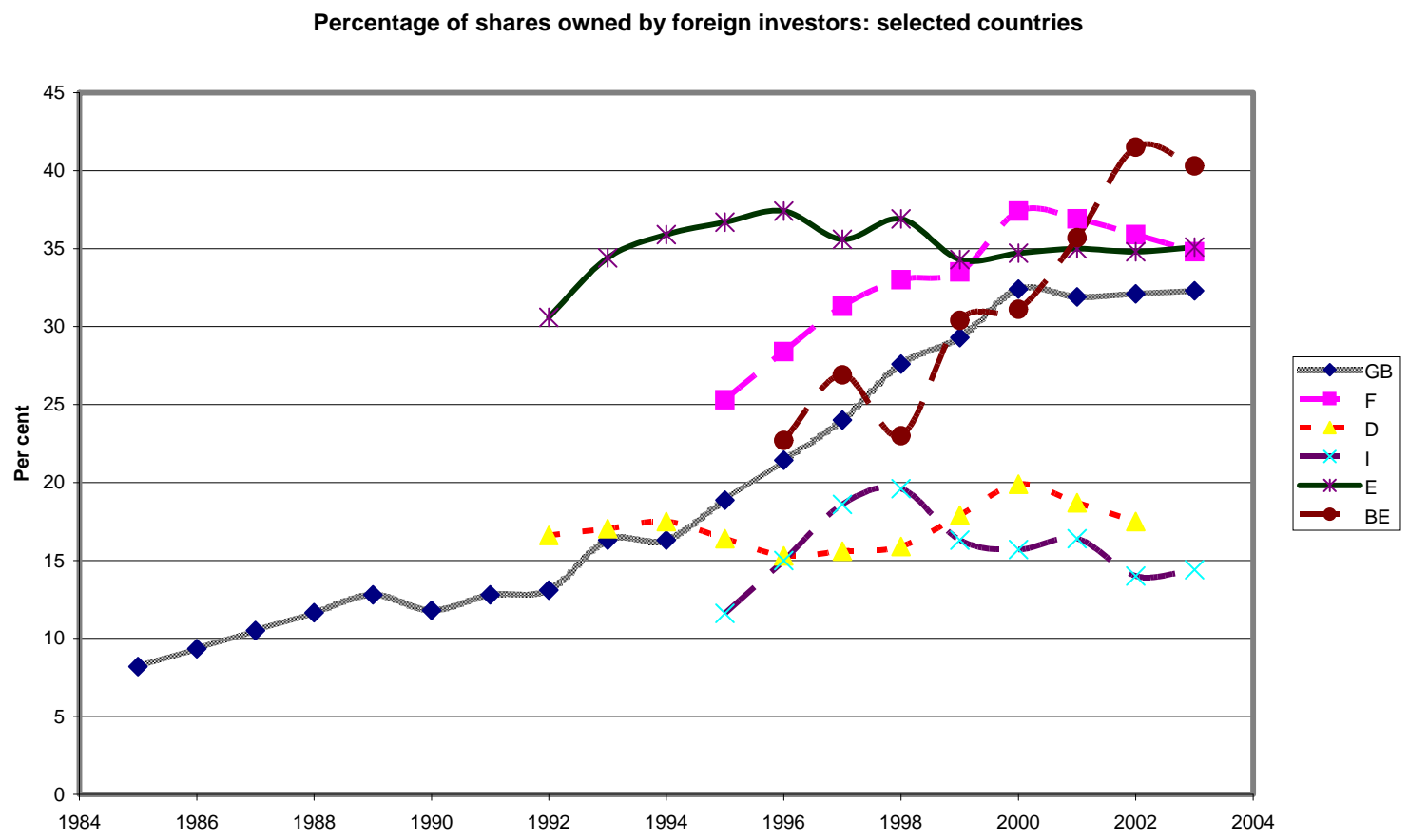

would be $\phi_{L}=14.4 \%$ in 2003, while the higher estimate would be just over $28 \%$ of the total. Most other European countries are considerably more internationalised still, as Appendix Table 2 shows. In this table, in most countries at least $1 / 3$ of shares are now foreign-owned, and the true figure may well be over $50 \%$ in most cases.

Data are missing for many European countries prior to 1995, and foreign shareowning fluctuates over time. However, Figure 1, below, shows that in a number of countries for which long time-series are available, the upward trend, decade-on-decade, is remarkable. For example, direct foreign share ownership in the UK rose from around $8 \%$ in 1985 to a third today.

Figure 1

Comparable data on foreign equity ownership in the United States are relatively hard to come by. BERTAUT et al [2006] estimate foreigners owned 10 per cent of U.S. equity in June 2005 - an increase from 5 per cent in 1994 - though their paper outlines a number of data issues. This number almost certainly excludes cases of wholly foreign-owned subsidiaries, which is why it does not tally easily with the FDI-based estimates used by DICK [1993]. 
Since $\phi$ is the share of post-tax profits which accrue to foreigners, we also need to correct for corporate taxation. From DEVEREUX AND GRIFFITH's database ${ }^{3}$ I use estimates of the effective average tax rate in 2005, adjusted for time- and country-specific inflation. These tax rates range from just under $20 \%$ to just over $30 \%$ in the selected sample of countries. When adjustment is made for this, then, for those countries on which tax and stock market ownership data are available, the lower estimate of the share of profits accruing to foreigners ranges from $10.8 \%$ in Italy to $52.4 \%$ in the Netherlands, while the higher estimate ranges from $21 \%$ in Italy to $63.7 \%$ in the Netherlands.

\section{Implications of foreign share ownership for protectionist policies: export subsidies with a duopoly}

The first example I choose to look at is the classic case of duopolists from two countries selling into a third country market. This is an issue given some prominence by the classic paper of BRANDER and SPENCER (1985), and, while the analysis is simplified, is widely regarded as having some relevance to real policy issues - notably the Boeing/Airbus dispute. This essentially looks at a two-stage game between the two firms and the two governments of their 'home' countries. Following a standard model formulation, I assume that the firms have identical costs and make indistinguishable products, and compete for the third country market in a subgame on the basis of Cournot conjectures about each other's output. The two exporting country governments, however, both have a potential motive to intervene in the export market, each subsidising 'its' firm's exports, with the intention of gaining a larger share of the market and hence a greater share of combined profits, which are supranormal because of the duopoly. In this higher-level game, each of the two governments is assumed to form a fixed conjecture of the other's likely subsidy level.

I assume initially that each country is small relative to the global financial economy, even though they are large relative to this particular industry. Consequently, while proportion $\phi$ of country 1's industry is owned by foreign-

\footnotetext{
${ }^{3}$ http://www.ifs.org.uk/publications.php?publication_id=3210. (as of Feb 9th, 2009) Details of the methodology are given in DEVEREAUX et al [2002].
} 
ers,country 1's ownership of shares in any one foreign country, 2, is assumed to be negligible. The effects of relaxing this assumption are discussed later in the paper. I also concentrate on the case where there are constant returns to scale. ${ }^{4}$

This problem has been solved in the linear demand case ${ }^{5}$ by DICK [1993] and NEARY [1994], ${ }^{6}$ with the result that, regardless of scale or cost asymmetries, the Brander-Spencer argument for subsidy always breaks down when the share of foreign ownership, $\phi=1 / 4$. Nevertheless, for comparison with the isoelastic demand case below, I lay out the main properties of the linear model (in the symmetric case) below, where the firms are denoted 1 and 2, and we are interested in the welfare effects of a subsidy $S$ in country 1 .

\begin{tabular}{|ll|}
\hline Linear Cournot Duopoly & \\
\hline \hline Inverse demand & $P=A-b\left(D_{1}+D_{2}\right)$. \\
Marginal cost & $C-S$ for firm 1 and $C$ for firm 2. \\
Marginal revenue firm 1 & $M R_{1}=\partial R_{1} / \partial D_{1}=A-2 b D_{1}-b D_{2}$. \\
Equilibrium output: firm 1 & $D_{1}=(A-C+2 S) / 3 b$. \\
Equilibrium output: firm 2 & $D_{2}=(A-C-S) / 3 b$. \\
Equilibrium price & $P=(A+2 C-S) / 3$. \\
Profit firm 1 & $\Pi_{1}=(A-C+2 S)^{2} / 9 b$. \\
Country 1's welfare & $W_{1}=(1-\phi) \Pi_{1}-(A-C+2 S) S / 3 b$. \\
Marginal welfare effect of $S$ & $\partial W_{1} / \partial S=4(1-\phi)(A-C+2 S) / 9 b$ \\
& $-(A-C+2 S) / 3 b-2 S / 3 b$. \\
\hline
\end{tabular}

Table 1: Summary of a linear, cross-hauling, Cournot duopoly selling into a third country market.

The threshold value of foreign ownership, $\phi=\widetilde{\phi}$, at which $\partial W_{1} / \partial S=0$ when $S=0$, is satisfied by $\phi=1 / 4$, as in the earlier papers.

As an alternative, however, it is worth comparing the result for an isoelastic demand model. This derives from a utility function

$$
U=\gamma D^{\eta}
$$

\footnotetext{
${ }^{4}$ As I want to focus solely on the profit-shifting motive in this paper (rather than infant industry type arguments), I concentrate on constant returns cases.

${ }^{5}$ Strictly speaking, both the linear demand model and the constant elasticity demand model are special cases, although in both cases it is possible to investigate a wide range of parameterisations by altering $A$ and $b$, or $\eta$ and $\gamma$ respectively.

${ }^{6}$ Footnote 2 of NEARY's [1994] paper. Neary treats foreign ownership of shares in a domestic firm as being equivalent to a higher local cost. In a linear Cournot model, a country will cease to subsidise its exports if its costs are more than $4 / 3$ those of the foreign firm: equivalent to saying that the critical threshold of foreign ownership is $1 / 4$.
} 
where $D=D_{1}+D_{2}$. I concentrate on the elastic demand case, where $0<$ $\eta<1$. $^{7}$ This generates an own-price elasticity of

$$
\varepsilon=1 /(\eta-1)
$$

for the combined output.

In a symmetric equilibrium, subsidies in the two countries are equal, so $S_{1}=S_{2}=S^{*}$. This can be summarised as follows, setting cost equal to $1-S_{i}$ (without loss of generality):

\begin{tabular}{|ll|}
\hline Cournot duopoly/isoelastic & Two firms exporting to a third country \\
\hline \hline Inverse demand & $P=\gamma \eta\left(D_{1}+D_{2}\right)^{\eta-1}$. \\
Marginal cost & $M C=1-S_{1}$ for firm $1,1-S_{2}$ for firm 2. \\
Combined demand & $D_{1}+D_{2}=\left[\left(M C_{1}+M C_{2}\right) /(\gamma \eta(1+\eta))\right]^{1 / \eta-1}$. \\
Relative shares & $\theta=D_{2} / D 1=\left(M C_{1}-\eta M C_{2}\right) /\left(M C_{2}-\eta M C_{1}\right)$. \\
Price in a symmetric equilbm & $P=2\left(1-S^{*}\right) /(1+\eta)$. \\
Firm 1's demand & $D_{1}=(P / \gamma \eta)^{1 /(\eta-1)} / 2$. \\
Marg effect of $S_{1}$ on & \\
\multicolumn{1}{r}{ relative shares } & $\partial \theta^{c} / d S_{1}=-\left((1+\eta) /\left((1-\eta)\left(1-S^{*}\right)\right)\right.$. \\
Marg effect on combd demand & $\partial D_{c} / \partial S_{1}=(4 /(1-\eta)(1+\eta))\left(D_{1} / P\right)$. \\
Marg effect on firm 1's demand & $\partial D_{1} / \partial S_{1}=(1 / 2)\left[\left(\partial D_{c} / \partial S_{1}\right)-D_{1}\left(\partial \theta^{c} / d S_{1}\right)\right]$. \\
Marg effect of $S_{1}$ on price & $\partial P / \partial S_{1}=-1 /(1+\eta)$. \\
Total welfare in country 1 & $W_{1}=D_{1}\left((1-\phi)(P-1)-\phi S_{1}\right)$ \\
Marg effect of $S_{1}$ on $W_{1} ;$ & $\partial W_{1} / \partial S_{1}=((1-\phi)(P-1)-\phi S)\left(\partial D_{1} / \partial S_{1}\right)$ \\
& $+(1-\phi) D_{1}\left(\partial P / \partial S_{1}\right)-\phi D_{1}$. \\
\hline
\end{tabular}

Table 2: Summary of an isoelastic, cross-hauling, Cournot duopoly selling into a third country market.

The solution is the value of $\phi=\widetilde{\phi}$ for which $\partial W_{1} / \partial S_{1}=0$ when $S^{*}=0$. By substitution, it can be shown that this is satisfied by $\phi=1 / 3$.

Proposition 1 In a scenario of two identical producers from different nations acting as a Cournot duopoly in a third country, where marginal costs are constant and the demand elasticity is constant, the Nash equilibrium subsidy level for the two governments will equal zero when foreign ownership

\footnotetext{
${ }^{7}$ Isoelastic duopoly models are usually restricted to the case with elastic demand. As BANDYOPADHYAY [1997] shows, an equilibrium is also possible for a duopoly (unlike with a monopoly) where demand is inelastic and the firms are symmetric, but the BranderSpencer result (that an export subsidy is desirable) is reversed. For the unitary elasticity case, neither a subsidy nor a tax is desirable.
} 
of shares is 1/3 of the total. This compares to a threshold value of foreign ownership of $1 / 4$ in a Cournot duopoly when demand is linear.

\section{Proof of Proposition 1}

The linear case has been proven before in DICK [1993] and NEARY [1994], and can be generalised to asymmetric cost functions. As a check, the condition is that $\partial W_{1} / \partial S=0$ when $S=0$ : this is found by setting

$$
\partial W_{1} / \partial S=4(1-\phi)(A-C+2 S) / 9 b-(A-C+2 S) / 3 b+2 S / 3 b=0 .
$$

I then set $S=0$, so

$$
\partial W_{1} / \partial S=4(1-\widetilde{\phi})(A-C) / 9 b-(A-C) / 3 b=0==>\widetilde{\phi}=1 / 4 .
$$

For the isoelastic demand case, we want to solve the set of equations above to find the value of $\phi=\phi^{*}$, which gives $S^{*}=0$. Consequently, we substitute for $S^{*}=0$ in $\partial W_{1} / \partial S_{1}$.

$\partial W_{1} / \partial S_{1}=\left((1-\phi)(P-1)-\phi S^{*}\right)\left(\partial D_{1} / \partial S_{1}\right)+(1-\phi) D_{1} \partial P / \partial S_{1}-\phi D_{1}^{*}=0$

Substituting into this equation for $P^{*}, D_{1}, \partial D_{1} / \partial S_{1}$ and $\partial P / \partial S==>$

$$
1+\eta=3(1+\eta) \phi^{*}
$$

$$
\phi^{*}=1 / 3
$$

Q.E.D.

It is worth noting that both critical values are probably now below the average level of foreign share ownership reported on most European stock markets at present.

\section{$5 \quad$ Entry of a Foreign Competitor to a Domes- tic Monopolist}

I now widen the discussion to models of entry or exit of a foreign firm to compete with a domestic monopolist. This can take a number of forms 
depending on the nature of the industry: in some cases, the good is internationally tradable, in which case the question is the setting of tariffs and/or non-tariff barriers to exclude the foreign firm. In the case of tariffs, the setup is essentially an extension of BRANDER AND SPENCER [1985], allowing for entry of the foreign firm.

Alternatively, the good or service concerned may not be easily tradable, but the government of the host country may be contemplating whether or not to allow entry of a foreign firm to challenge a national champion. This example could be seen as a case of 'economic patriotism': 8 a loosely-defined term, which appears to be mostly concerned with preventing foreign entry into 'strategic' industries and takeover of 'national champion' companies. In some service industries, such as privatised utilities, the only way to enter is by FDI.

\subsection{The linear Cournot duopoly}

I will start by examining the profit-shifting motive for protection in the case of a linear, Cournot duopoly. We should note in passing that, in the case of protecting a local champion against a potential importer, a country's preferred method of protection, ceteris paribus, would be tariffs, which raise revenue. However, due to issues of the visibility of tariffs, advanced countries generally resort to regulatory protection instead. I summarise both cases here. The model, which is summarised in EDWARDS [2007], assumes that the two firms have unit costs $C_{1}$ and $C_{2}$, but that firm 2, which is foreign, faces an additional iceberg cost per unit, $\tau$, to overcome regulatory barriers to entering the market. These regulations are assumed to be of the pure, horizontal variety (i.e. they do not add to welfare in the importing country). The model can be summarised as follows:

${ }^{8}$ http://news.bbc.co.uk/2/hi/europe/4837150.stm (Last visited 9th Feb 2008) refers to the De Villepin government in France and its 'economic patriotism' agenda. Also see GROS [2006]. 


\begin{tabular}{|ll|}
\hline Linear Cournot duopoly & with regulatory barrier $\tau$ and tariff $t$ \\
\hline Inverse demand & $P=A-b\left(D_{1}+D_{2}\right)$. \\
Firm 1 marg cost & $C_{1}$. \\
Firm 2 marg cost & $C 2+t+\tau$. \\
Marginal revenue firm 1 & $M R_{1}=A-2 b D_{1}-b D_{2}^{*}$. Firm 2 is equivalent \\
Equilibrium output firm 1 & $D_{1}=\left(A-2 C_{1}+C_{2}+t+\tau\right) / 3 b$. \\
Equilibrium output firm 2 & $D_{2}=\left(A+C_{1}-2 C_{2}-2 t-2 \tau\right) / 3 b$. \\
Equilibrium price & $P=\left(A+C_{1}+C_{2}+t+\tau\right) / 3$. \\
Firm 1 profits & $\Pi_{1}=\left(A-2 C_{1}+C_{2}+t+\tau\right)^{2} / 9 b$. \\
Consumer surplus & $V=\left(2 A-C_{1}-C_{2}-t-\tau\right)^{2} / 18 b$. \\
Tariff revenue & $T=t\left(A+C_{1}-2 C_{2}-2 t-2 \tau\right) / 3 b$. \\
Marg effect of $\tau, t$ on $\Pi_{1}$ & $\partial \Pi_{1} / \partial \tau=\partial \Pi_{1} / \partial t=2\left(A-2 C_{1}+C_{2}+t+\tau\right) / 9 b$. \\
Marg effect of $\tau, t$ on $V$ & $\partial V / \partial \tau=\partial V / \partial t=-\left(2 A-C_{1}-C_{2}-t-\tau\right) / 9 b$. \\
Marg effect $t$ on tar rev & $\partial T / \partial t=\left(A+C_{1}-2 C_{2}-4 t-2 \tau\right) / 3 b$. \\
Welfare in country 1 & $W_{1}=(1-\phi) \Pi_{1}+V+T$. \\
Marg effect of $\tau$ on $W_{1}$ & $\partial W_{1} / \partial \tau=\left(C_{2}-C_{1}+t+\tau\right) / 3 b$ \\
& $-2 \phi\left(A-2 C_{1}+C_{2}+t+\tau\right) / 9 b$. \\
Marg effect of $t$ on $W_{1}$ & $\partial W_{1} / \partial t=\left(A-C_{2}-3 t-\tau\right) / 3 b$ \\
& $-2 \phi\left(A-2 C_{1}+C_{2}+t+\tau\right) / 9 b$. \\
\hline
\end{tabular}

Table 3: Summary of a linear, Cournot duopoly with a foreign and domestic firm.

\subsubsection{Setting of tariffs}

EDWARDS [2007] discusses the interaction of tariffs and non-tariff barriers in this model. If the home country is free to set tariffs, then it will never use non-tariff barriers (quotas or horizontal regulatory barriers) to exclude the foreign firm, since the latter yield no revenue. Consequently, we can assume $\tau=0$. It follows that

$$
\partial W_{1} / \partial t=\left(A-C_{2}-3 t\right) / 3 b-2 \phi\left(A-2 C_{1}+C_{2}+t\right) / 9 b .
$$

Setting this equal to zero gives us a relationship between $\phi$ and the welfare-maximising tariff, $t^{*}$.

$$
\begin{aligned}
\partial W_{1} / \partial t & =0==>(3-2 \phi)\left(A-C_{2}\right)+4 \phi\left(C_{1}-C_{2}\right)=(2 \phi+9) t^{*} \\
t^{*} & =\left[(3-2 \phi)\left(A-C_{2}\right)+4 \phi\left(C_{1}-C_{2}\right)\right] /(2 \phi+9) .
\end{aligned}
$$


Note first that, where $C_{1}=C_{2}=C$, we can derive

$$
t^{*}=(3-2 \phi)(A-C) /(2 \phi+9) \text {. }
$$

From this follows

Lemma 2 When there is no foreign ownership, the welfare-maximising tariff for country 1 is $(A-C) / 3$.

Lemma 3 When there is total foreign ownership, the welfare-maximising tariff for country 1 is $(A-C) / 11$.

Both lemmas follow from substituting $\phi=0$ or $\phi=1$ in equation (6).

Lemma 4 The welfare-maximising tariff declines monotonically as foreign ownership increases.

This follows from differentiating (7) with respect to $\phi$ and rearranging:

$$
\partial t^{*} / \partial \phi=-2 t^{*} /(3-2 \phi)-2 t^{*} /(2 \phi+9) .
$$

Since $0 \leqslant \phi \leqslant 1$, this will be negative.

From these lemmas follows

Proposition 5 In a symmetric, linear Cournot model, where the two firms have identical costs (before including the tariff) the welfare-maximising tariff, $t^{*}$, will always be positive, even if foreign ownership is $100 \%$.

From inspection of (6), we can see that the welfare-maximising tariff will be lower if the foreign firm is the lower-cost producer. For a given value of $C_{1}, \partial t^{*} / \partial C_{2}<0$. Alternatively, setting $t^{*}=0$, (6) can be rewritten as

$$
\Delta=(3-2 \phi) / 2 \phi \text {. }
$$

where

$$
\Delta=\left(C_{2}-C_{1}\right) /\left(A-C_{1}\right) .
$$

From this we can derive that, when foreign ownership is $100 \%, t^{*}$ falls to zero when $\Delta=1 / 2$, but that, even when foreign ownership is $75 \%, C_{2}$ must already be higher than the demand intercept $A$.

An intuitive explanation why tariff-setting is less affected by the foreign ownership of local firms than in the other scenarios examined in this paper is that tariffs are justified, at least partly, by extraction of producer rent from foreign firms in the form of tariff revenue, rather than simply by profitshifting. 


\subsubsection{Regulatory protection}

Tariffs are often ruled out by international agreements, or are seen as too visible. Consequently, it is widely argued ${ }^{9}$ that countries will resort to regulatory protection to keep foreign firms out. EDWARDS [2007] looks at the use of pure, horizontal regulatory protection in a linear model, and shows that it is quite different in its implications to the situation where the home country is free to apply tariffs.

Throughout this subsection, I consider the properties of the linear Cournot duopoly model, when $t$ is constrained to equal zero. First, consider the situation when $\phi=0$ :

Lemma 6 When there is no foreign-ownership of firm 1, then welfare in country 1 is initially increasing with respect to the regulatory barrier, $\tau$, unless $C_{2}$ is less than $C_{1}$.

This lemma is proven by setting $\phi=0$, so that $\partial W_{1}^{*} / \partial \tau=\left(C_{2}-C_{1}+\right.$ $\tau) / 3 b$.

Also

Lemma 7 When there is no foreign ownership, the marginal gain to country 1 from increasing the regulatory barrier, $\tau$, is monotonically increasing with respect to $\tau$.

This follows from setting $\phi=0$, and differentiating $\partial W_{1}^{*} / \partial \tau$ again with respect to $\tau$.

From these two lemmas follows the proposition:

Proposition 8 In a linear Cournot duopoly, in the absence of foreign ownership, and when tariffs are ruled out, country 1 will prefer to raise the regulatory barrier to the point where the foreign firm is totally excluded, unless $C_{1}$ is sufficiently larger than $C_{2}$.

The logic behind this proposition is that Lemma 4 shows that, starting from zero protection, the initial marginal welfare effect of raising $\tau$ is positive, while Lemma 5 shows that subsequent increases in $\tau$ produce still larger welfare gains, until the foreign firm is driven out completely.

\footnotetext{
${ }^{9}$ MASKUS AND WILSON [2001].
} 
EDWARDS [2007] shows that 'sufficiently larger' in this case means

$$
\left|C_{1}-C_{2}\right|<\left|A-C_{1}\right| / 2 .
$$

We now want to ask whether, and how, this total exclusion result is changed when there is some foreign ownership of firm 1. Doubly differentiating $W_{1}$ with respect to $\tau$, we find that

$$
\begin{aligned}
\partial W_{1} / \partial \tau & =\left(C_{2}-C_{1}+\tau\right) / 3 b-2 \phi\left(A-2 C_{1}+C_{2}+\tau\right) / 9 b \\
\partial^{2} W_{1} / \partial \tau^{2} & =(3-2 \phi) / 9 b
\end{aligned}
$$

For a given value of $\phi$ between 0 and $1, \partial^{2} W_{1} / \partial \tau^{2}$ is constant and positive. There will only be one turning-point for $W_{1}$ with respect to $\tau$, and this will be a minimum. Looking at the range of $\tau$ from 0 up to the point where the foreign firm is excluded, the optimal value of $\tau$ will not be an interior point (since there is only one turning-point, which is a minimum, not a maximum). There follows

Lemma 9 When foreign ownership is introduced in the linear Cournot model, and protection takes the form of horizontal regulatory protection, the importing country government's preferred solution will be either no protection or total exclusion of the foreign firm.

To see which solution will be preferred, it is also necessary to compare the solution with that of a monopoly, where the foreign firm has been totally excluded from the market.

\begin{tabular}{|lll|}
\hline \multicolumn{2}{|c|}{ Monopoly } & Duopoly \\
\hline Inverse demand & $P=A-b D_{1}$. & $P=A-b\left(D_{1}+D_{2}\right)$. \\
Marginal cost & $M C=C_{1}$. & $M C=C_{1}$ or $C_{2}$ \\
Output firm 1 & $D_{1 M}=\left(A-C_{1}\right) / 2 b$. & $D_{1 D}=\left(A-2 C_{1}+C_{2}\right) / 3 b$ \\
Output firm 2 & & $D_{2 D}=\left(A+C_{1}-2 C_{2}\right) / 3 b$ \\
Price & $P_{M}=\left(A+C_{1}\right) / 2$. & $P_{D}=\left(A+C_{1}+C_{2}\right) / 3$. \\
Profit firm 1 & $\Pi_{1 M}=\left(A-C_{1}\right)^{2} / 4 b$. & $\Pi_{1 D}=\left(A-2 C_{1}+C_{2}\right)^{2} / 9 b$ \\
Cons surplus & $V_{M}=\left(A-C_{1}\right)^{2} / 8 b$. & $V_{D}=\left(2 A-C_{1}-C_{2}\right)^{2} / 18 b$. \\
Welfare & $W_{1 M}=(3-2 \phi)\left(A-C_{1}\right)^{2} / 8 b$. & $W_{1 D}=\left[2(1-\phi)\left(A-2 C_{1}+C_{2}\right)^{2}\right.$ \\
& & $\left.+\left(2 A-C_{1}-C_{2}\right)^{2}\right] / 18 b$. \\
\hline
\end{tabular}

Table 4: Comparison in the linear case of a local monopoly versus a Cournot duopoly with a foreign entrant.

From the above, we can deduce that, 
Proposition 10 In a linear Cournot model, when costs are symmetric between the two firms, the importing country's government will prefer to exclude the foreign firm if and only if foreign ownership of its domestic firm is less than thirty per cent.

\section{Proof of Proposition 4}

Note that

$$
\begin{aligned}
& W_{1 M}^{*}=(3-2 \phi)\left(A-C_{1}\right)^{2} / 8 b \\
& W_{1 D}^{*}=(3-\phi)\left(A-C_{1}\right)^{2} / 9 b,
\end{aligned}
$$

where the asterisk indicates the situation where costs of the two firms are equal. The value of $\phi=\widehat{\phi}$, which equates $W_{1 M}^{*}$ with $W_{1 D}^{*}$, is found by rearranging these equations:

$$
\begin{aligned}
(3-2 \widehat{\phi}) / 8 & =(3-\widehat{\phi}) / 9 \\
\widehat{\phi} & =3 / 10
\end{aligned}
$$

Q.E.D.

The 30\% threshold in Proposition 4 is interesting as, once again, it lies below the current levels of foreign ownership in many countries, whereas a decade ago this was not the case.

It is also interesting to see how this is altered in the case of differential costs for the two firms. Given the relative complexity of the equations, a numerical solution method is applied, as shown in Table 5, below.

\begin{tabular}{|l|lllll|}
\hline & \multicolumn{5}{|c|}{$C_{2} / C_{1}$} \\
$A / C_{1}$ & $\mathbf{0 . 6}$ & $\mathbf{0 . 8}$ & $\mathbf{1}$ & $\mathbf{1 . 2}$ & $\mathbf{1 . 4}$ \\
\hline $\mathbf{1 . 5}$ & 0.00 & 0.07 & 0.3 & 0.47 & 0.59 \\
$\mathbf{2}$ & 0.07 & 0.2 & 0.3 & 0.39 & 0.47 \\
$\mathbf{2 . 5}$ & 0.16 & 0.23 & 0.3 & 0.36 & 0.42 \\
$\mathbf{3}$ & 0.20 & 0.25 & 0.3 & 0.35 & 0.39 \\
$\mathbf{3 . 5}$ & 0.22 & 0.26 & 0.3 & 0.34 & 0.37 \\
$\mathbf{4}$ & 0.23 & 0.27 & 0.3 & 0.33 & 0.36 \\
$\mathbf{4 . 5}$ & 0.24 & 0.27 & 0.3 & 0.33 & 0.35 \\
$\mathbf{5}$ & 0.25 & 0.28 & 0.3 & 0.32 & 0.35 \\
\hline
\end{tabular}

Table 5: Critical foreign ownership share for excluding a foreign competitor to a domestic monopolist: linear demand. 
In the calculations, I have set $C_{1}=1$, without loss of generality. The figure shows that, whenever production costs are equal $\left(C_{2}=C_{1}=1\right)$, the critical value of $\phi$ is 0.3 , as in Proposition 4. However, when the foreign firm's costs are lower than the domestic firm, the critical threshold value of $\phi$ is lower, so that only with very low levels of foreign ownership will the home country choose to exclude the foreign firm. This is particularly true when the demand intercept, $A$, is relatively low. By contrast, if the foreign firm has much higher costs than the domestic firm, the home country may prefer to exclude it even when a higher proportion of its domestic firm is foreign-owned.

\subsection{A Cournot duopoly with isoelastic demand}

Again, I will concentrate on the case where a foreign firm seeks - maybe as part of a general industry deregulation - to move in to challenge a local monopolist. Given that this is a complicated model to solve, I will concentrate on the case where costs of the two firms are symmetric (normalised at $\$ 1$ per unit) and where the government's choice is simply one of excluding the foreign firm totally or allowing it to enter. ${ }^{10}$

The choice facing the government of the host country is therefore whether to persist with a protected monopoly (I assume there is no price regulation) or to allow the foreign firm to enter and create a duopoly. In the latter situation, prices will be lower and output higher, so benefiting consumers. Half of the duopoly profits, however, will be sent abroad. The foreign firm is entirely foreign-owned, whereas share $(1-\phi)$ of the domestic firm is owned by domestic residents. I will ignore profit taxes in this simple analysis, though they serve, in practice, to reduce $\phi$.

Consumers have a utility function as in (3) above. The outcomes under a monopoly and a symmetric Cournot duopoly are:

\footnotetext{
${ }^{10}$ This might correspond to allowing a foreign competitor to challenge a local, privatised utility.
} 


\begin{tabular}{|c|c|c|}
\hline Isoelastic demd & Monopoly & Symmetric Cournot Duopoly \\
\hline Inverse demand & 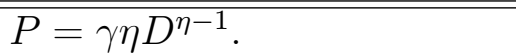 & $\bar{c} \gamma \eta\left(D_{1 C}+D_{2 C}\right)^{\eta-1}$ \\
\hline Marg cost firm 1 & $M C=1$ & $M C=1$ \\
\hline Marg cost firm 2 & $\cdot$ & $M C=1$ \\
\hline Output firm 1 & $D_{M}=\left(\gamma \eta^{2}\right)^{1 / 1-\eta}$ & $D_{1 C}=(\gamma \eta(1+\eta) / 2)^{1 /(1-\eta)} / 2$. \\
\hline Output firm 2 & & $D_{2 C}=(\gamma \eta(1+\eta) / 2)^{1 /(1-\eta)} / 2$ \\
\hline Price & $P_{M}=1 / \eta$ & $P_{C}=2 /(1+\eta)$ \\
\hline Profit firm 1 & $\Pi_{M}=\left(\gamma \eta^{2}\right)^{1 / 1-\eta}((1-\eta) / \eta)$ & $\begin{array}{r}\Pi_{1 C}=\left((\gamma \eta(1+\eta) / 2)^{1 /(1-\eta)}-1\right) \\
(2 /(1+\eta))\end{array}$ \\
\hline Cons surplus & $V_{M}=\gamma\left(\gamma \eta^{2}\right)^{\eta / 1-\eta}\left(1-\gamma \eta^{2}\right)$ & $\begin{array}{r}V_{C}=(\gamma \eta(1+\eta) / 2)^{\eta /(1-\eta)} \\
(1-(\gamma \eta(1+\eta) / 2)) \\
(2 \gamma /(1+\eta))\end{array}$ \\
\hline Welfare $(f / g 9)$ & $(1-\phi) \Pi_{M}+V_{M}$ & $(1-\phi) \Pi_{M}+V_{M}$ \\
\hline
\end{tabular}

Table 6: Summary of an isoelastic monopoly versus a Cournot duopoly with a foreign entrant.

Solution and comparison Rather than solving these two models algebraically, it is more sensible in this case to carry out a numerical simulation for each model, based upon alternative values of $\varepsilon$ and $\phi$. The scale parameter, $\gamma$, can be shown to have no effect on whether the country will prefer a protected monopoly or a duopoly.

In general, the more elastic demand is (the higher $\varepsilon$ or the lower $\eta$ is), the more likely, other things equal, a country will prefer 'economic patriotism'. This is because the costs of monopoly, in terms of loss of consumer surplus, are less when demand is elastic. There is therefore a critical threshold elasticity, $\varepsilon^{*}$, above which the country will prefer a domestic monopoly to a half-foreign duopoly. Simulations show that, when there is no foreign share-ownership in the domestic firm (i.e. $\phi=0$ ), the critical value $\varepsilon^{*}$ lies at around 2.7. It is worth noting this critical elasticity probably lies well above the demand elasticity for some monopolistic services (such as water or electricity $^{11}$ ), but it is possibly lower than that for some goods subsectors, or particularly for goods suppliers where there is a single domestic supplier competing with a foreign competitive fringe. ${ }^{12}$ It is therefore quite con-

\footnotetext{
${ }^{11}$ Although the actions of a price regulator may make these industries behave as if they had a higher demand elasticity.

${ }^{12}$ For example, a recent survey article by ANDERSON AND VAN WINCOOP [2003] indicates that most traded goods have elasticities of substitution between different national
} 
ceivable that national champions in many industries may be protected for profit-shifting reasons.

Now consider the impact of allowing $\phi$ to alter, representing a rise in foreign share ownership. Simulations indicate the following relationship:

\begin{tabular}{|ll|}
\hline Foreign share $\phi$ & Critical elasticity $\varepsilon^{*}$ \\
\hline $0 \%$ & 2.7 \\
$5 \%$ & 3.0 \\
$10 \%$ & 3.6 \\
$15 \%$ & 4.4 \\
$20 \%$ & 5.9 \\
$25 \%$ & 9.1 \\
$30 \%$ & 20.0 \\
\hline
\end{tabular}

Table 7: Relationship between foreign share and critical elasticity for protecting a domestic monopoly.

The pattern shown in Table 7 indicates that, at low share ownership levels, the marginal effect of raising foreign share ownership on the critical elasticity is not great: however, it becomes increasingly important, and once foreign share ownership rises above $20 \%$ the curve becomes steep. In other words, at the kind of foreign share-ownership level seen in most European countries today, the profit-shifting case for protection of a domestic monopolist breaks down quite rapidly.

\section{Further considerations}

\subsection{FDI and international share ownership}

DICK (1993) based his estimates of the effects of international ownership on US Department of Commerce estimates for 1986 of the stock of foreign direct investment in the USA. By contrast, most of the analysis in the first part of my paper is based upon estimates of foreign ownership of the stock markets of various countries. Both types of foreign investment are of relevant to the profit-shifting debate, but in different ways. FDI, in the form of complete ownership by foreigners of a local subsidiary, is the more visible form of foreign share ownership, yet the debate over 'national champions' generally focuses on firms which appear, at first sight, not to be foreign-owned (or at least not primarily foreign-owned). The international share-ownership

producers of between 5 and 10 . 
statistics from FESE indicate that, even when a firm is not explicitly foreignowned, a high proportion of its profits may still, in fact, end up in the hands of foreigners.

A recent mimeo paper by ISHIKAWA et al [2007] examines the interesting circumstances of partial FDI - in other words, the situation where a significant proportion of its shares is owned by a foreign rival, even if the company is still quoted on the local stock exchange. This is undoubtedly an explanation of some cross-border share ownership (though not all), and does introduce interesting issues of mixed motivations for the subsidiary company. ${ }^{13}$ This situation is somewhat more complex than those analysed in this paper.

\subsection{Two-way share ownership}

A further complication is that, not only do foreigners own a significant proportion, $\phi$, of shares in country 1 , but residents in country 1 may own a proportion $\psi$ of shares in the rival firm based in country 2 . While this is undoubtedly a possibility, it is most relevant in the two-country case examined in LEE's [1990] paper on cross-ownership. In most cases, at least where we are looking at individual European countries, the value of $\psi$ is likely to be much smaller than that of $\phi$, due to the presence of many third-party countries. However, one qualification to this comes when we are looking at protectionism taken at the level of regional groupings or very large nations (say, the EU versus the United States), in which case $\psi$ may no longer be small. For this reason, in Appendix 2, I rework a number of the equations in the previous sections, taking account of two-directional ownership. In general, if a proportion of the foreign firm is owned by country 1 residents, then the protectionist motive is weakened further.

To summarise:

In the linear, Cournot model of two firms competing in a third market (section 3), there ceases to be a motive for export subsidies when

$$
\phi^{*}=(1 / 4)-\psi / 2
$$

This presumably corresponds to one of the lines shown graphically in LEE's [1990] figure 2. This reduces to $\phi^{*}=(1 / 4)$ when $\psi=0$.

\footnotetext{
${ }^{13}$ Under some circumstances, in some ranges of foreign ownership, a tariff may cause production to shift from the foreign firm to its local subsidiary, squeezing out properly locally-owned firms.
} 
In the linear, Cournot model of using a tariff to protect a domestic firm against a rival (section 4.1), and confining ourself to the case with symmetric costs, the welfare-maximising import tariff is given by

$$
t^{*} /(A-C)=(3-2 \phi-\psi) /(9+2 \phi+4 \psi) .
$$

For the regulatory protection setup in 4.1.2, the linear Cournot model gives us a critical threshold

$$
10 \phi+8 \psi=3
$$

At levels of international ownership exceeding this, assuming tariffs are ruled out, country $A$ will prefer to use regulatory protection or total exclusion of the foreign firm, while at lower levels, it will not resort to regulatory protection. Again, if $\psi=0$, this reduces to $\phi^{*}=0.3$.

\section{Summary and Conclusions}

BRANDER AND SPENCER [1985] established the idea that profit-shifting in oligopolistic industries could be a major motivation for protection. This was at a time when the great bulk of shares in any major country's firms were usually held by domestic nationals. This situation has been steadily changing in the subsequent years, as national champion firms have been privatised and as financial markets have become globalised. Analysis of the case of the United States around 1989 by DICK [1993] suggested that the optimal subsidy for an American-based exporting firm in a linear Cournot duopoly setup was roughly half what the original BRANDER-SPENCER [1985] analysis suggested.

In this paper, I suggest that the current effect of international share ownership, at least in European economies, for which good data are available, is far greater even than Dick suggested. Analysis of European data suggests that typical share-ownership by foreigners is now over a third in many countries, and this could well be a significant underestimate. Even when account is taken of corporate taxation, the share of profits accruing to foreigners is 20-30 per cent in most countries on the lower estimate, while, on a higher estimate, taking account of indirect share ownership, it may well be over half in many cases. In a classic duopoly setup for a third country market, this would be enough to invalidate profit-shift on its own as a motive for 
export subsidy, both in a linear Cournot duopoly and (more marginally) in a duopoly with isoelastic demand, where optimal subsidies become negative when foreign ownership exceeds $1 / 3$ (against $1 / 4$ in the linear case).

As a consequence of this, I look at a somewhat wider class of duopoly scenarios, to gain an idea of the likely point, in practice, at which the subsidising or protectionist motive will break down, as foreign share ownership rises. For example, the use of pure horizontal regulatory protection (MASKUS AND WILSON, eds [2001]) to keep out a competitor to a national champion on profit-shifting grounds is invalidated in a linear Cournot duopoly model when foreign ownership of the domestic firm reaches $30 \%$. With a Cournot model with isoelastic demand, based on common estimates of demand elasticities, the critical threshold share is likely to be somewhat lower.

A consequence, at least as far as individual European countries is concerned, is that profit-shifting on its own is no longer likely to provide an economic justification for 'economic patriotism'. This does not mean there is no profit-shifting, ${ }^{14}$ but profit-shifting will only justify protection at the margin when combined with other factors, such as scale economies or general equilibrium terms-of-trade arguments. An example of this is the setting of welfare-maximising tariffs on a foreign competitor to a local firm (section 4.1.1). In this case, there is an additional motive for protection: revenueraising. In a linear Cournot duopoly, an increase in foreign ownership of the domestic firm would reduce the tariff from $33.33 \%$ of the difference between at zero foreign ownership to $25 \%$ with 30 per cent foreign ownership and $20 \%$ with half the shares owned by foreigners ${ }^{15}$. This is the only scenario, of those examined here, where European countries would still have a justification for protection - yet, even here, rising international share ownership means that, year-on-year, profit-shifting is getting less important.

One caveat to this is that economic decisions are increasingly being taken at the level of regional blocs, such as the European Union. Since some shares within EU countries are held by residents of other EU countries, the level of non-EU ownership of EU shares will be less than that of all foreigners in the market of an individual EU country, so weakening the international ownership effect. Against this, EU residents will own a significant proportion of shares in many non-EU countries.

\footnotetext{
${ }^{14}$ Presumably that would only happen when the average of the domestic share of the foreign firm and foreigners' share of the domestic firm reaches $50 \%$.

${ }^{15}$ Based on equation (6).
} 
A second caveat is that governments' or electorates' perceptions may not yet have caught up with the developments in firm ownership. Consequently, it is quite possible that protectionist policies and 'economic patriotism' may survive for some time yet, even when they make no economic sense for the countries concerned.

\section{Appendix}

\section{Appendix 1: Tables}

\begin{tabular}{|c|c|c|c|c|c|}
\hline & & Germany* & France & UK & Italy \\
\hline \multirow{8}{*}{$\begin{array}{l}\text { Foreign } \\
\text { Domestic }\end{array}$} & & 17.5 & 34.8 & 32.3 & $14.4 \%$ \\
\hline & Collective investment & 9.5 & 28.5 & 50.9 & $10.6 \%$ \\
\hline & Banks and savings banks & 7.5 & 13.3 & 2.2 & $5.2 \%$ \\
\hline & Bond Issuing Mortgage cos & & 11.1 & & \\
\hline & Others not identified & & & & $3.3 \%$ \\
\hline & Private Non-Financial cos & 45.6 & 23.7 & 1.9 & $29.7 \%$ \\
\hline & Individual investors/hholds & 14.1 & 8.5 & 14.9 & $26.6 \%$ \\
\hline & Public sector & 5.8 & 4.5 & 0.0 & $10.2 \%$ \\
\hline
\end{tabular}




\begin{tabular}{|lll|}
\hline (source FESE* & Foreign \% of total & Foreign \% of foreign+indiv+public \\
\hline Slovakia & 86.0 & 97.7 \\
Hungary & 72.6 & 84.6 \\
Netherlands & 69.0 & 84.1 \\
Poland & 53.0 & 88.2 \\
Lithuania & 51.8 & 81.7 \\
Belgium & 40.3 & 78.9 \\
Australia & 40.0 & 64.5 \\
Portugal & 38.9 & 70.3 \\
Spain & 35.1 & 57.2 \\
France & 34.8 & 72.8 \\
Sweden & 33.2 & 55.1 \\
UK & 32.3 & 68.4 \\
Greece & 31.3 & 51.2 \\
Norway & 27.8 & 36.9 \\
Denmark & 27.3 & 51.9 \\
Japan & 23.7 & 53.6 \\
Germany & 17.5 & 46.8 \\
Italy & 14.4 & 28.1 \\
Slovenia & 8.0 & 15.5 \\
\hline
\end{tabular}

Appendix Table 2: The share of foreign ownership in various stock markets, latest (2003 for most, 2004 for Japan and Australia, 2002 for Germany). * Sources for Australia ASX (Australian Securities Exchange), for Japan World Federation of Exchanges. 


\begin{tabular}{|llll|}
\hline & Tax & Lower & Higher \\
\hline Belgium & 25.7 & 29.9 & 58.6 \\
France & 24.6 & 26.2 & 54.9 \\
Germany & 30.1 & 12.2 & 32.7 \\
Greece & 20.5 & 24.9 & 40.7 \\
Italy & 25.2 & 10.8 & 21.0 \\
Norway & 23.1 & 21.4 & 28.3 \\
Portugal & 19.7 & 32.1 & 56.5 \\
Spain & 25.9 & 26.0 & 42.3 \\
Sweden & 20.1 & 26.5 & 44.0 \\
Netherlands & 24.1 & 52.4 & 63.9 \\
UK & 23.1 & 24.9 & 52.7 \\
Japan & 29.2 & 16.8 & 37.9 \\
Australia & 25.7 & 29.7 & 47.9 \\
\hline
\end{tabular}

Table 3: Effective average corporate taxation and lower and higher estimates of the share of profits accruing abroad.

\section{Appendix 2: Cross-ownership of shares}

In the main paper, I assume simply that proportion $\phi$ of shares in the home firm is owned by foreigners. However, a proportion $\psi$ of shares in the foreign competitor will be owned by inhabitants of the home country. Normally, we would assume $\psi<\phi$, and $\psi$ may well be close to zero. However, in the case of large nations or economic groupings, such as the United States or the European Union, $\psi$ may be large enough to be significant. In this Appendix, I look at the effects on some of the games outlined in the main paper of allowing $\psi$ to be non-zero.

\subsubsection{Two exporters to a third country market: linear Cournot model.}

To the table in the main paper, we need to add:

Profit firm 2

$\Pi_{2}=(A-C-S)^{2} / 9 b$.

Welfare country 1

$W_{1}^{\prime}=(1-\phi) \Pi_{1}+\psi \Pi_{2}-(A-C+2 S) S / 3 b$.

Marginal welfare effect of $S$

$$
\partial W_{1}^{\prime} / \partial S=4(1-\phi)(A-C+2 S) / 9 b
$$

$-2 \psi(A-C-S) / 9 b$

$-(A-C-S) / 3 b+2 S / 3 b$. 
Setting $S=0$, we want the combination of values of $\phi$ and $\psi$ for which $\partial W_{1}^{\prime} / \partial S=0$ :

$$
\begin{aligned}
4(1-\phi)(A-C) / 9 b-(2 \psi+3)(A-C) / 9 b & =0 \\
1-4 \phi-2 \psi & =0 \\
\phi & =(1 / 4)-\psi / 2
\end{aligned}
$$

This produces a critical threshold for values of $\{\phi, \psi\}$.

\subsection{Taxation of a foreign competitor.}

I look at the symmetric model only.

With tariff $t$ and regulatory barrier $\tau$

Firm 1 profits $\quad \Pi_{1}=(A-C+t+\tau)^{2} / 9 b$.

Firm 2 profits $\quad \Pi_{2}=(A-C-2 t-2 \tau)(A-C+t+\tau) / 9 b$.

Consumer surplus $V=(2 A-2 C-t-\tau)^{2} / 18 b$.

Tariff revenue $\quad T=t(A-C-2 t-2 \tau) / 3 b$.

Welfare country $1 \quad W_{1}^{\prime}=(1-\phi) \Pi_{1}+\psi \Pi_{2}+V+T$.

With $\tau=0 \quad \partial \Pi_{1} / \partial t=2(A-C+t) / 9 b$.

$\partial \Pi_{2} / \partial t=(-(A-C)-4 t) / 9 b$.

$\partial V / \partial t=-(2 A-2 C-t) / 9 b$.

$\partial T / \partial t=(A-C-4 t-2 \tau) / 3 b$.

$$
\begin{aligned}
\partial W_{1}^{\prime} / \partial t= & 2(A-C+t) / 9 b-2 \phi(A-C+t) / 9 b \\
& -\psi((A-C)+4 t) / 9 b-(2 A-2 C-t) / 9 b+3(A-C-4 t) / 9 b, \\
= & (1 / 9 b)[(A-C)(2-2 \phi-\psi-2+3)+t(2-2 \phi-4 \psi+1-12)], \\
= & (1 / 9 b)[(A-C)(3-2 \phi-\psi)-t(9+2 \phi+4 \psi)]
\end{aligned}
$$

Setting $\partial W_{1}^{\prime} / \partial t=0$ :

$$
\begin{aligned}
(A-C)(3-2 \phi-\psi) & =t^{*}(9+2 \phi+4 \psi) \\
t^{*} /(A-C) & =(3-2 \phi-\psi) /(9+2 \phi+4 \psi) .
\end{aligned}
$$




\subsection{Total exclusion of a foreign competitor to a na- tional champion.}

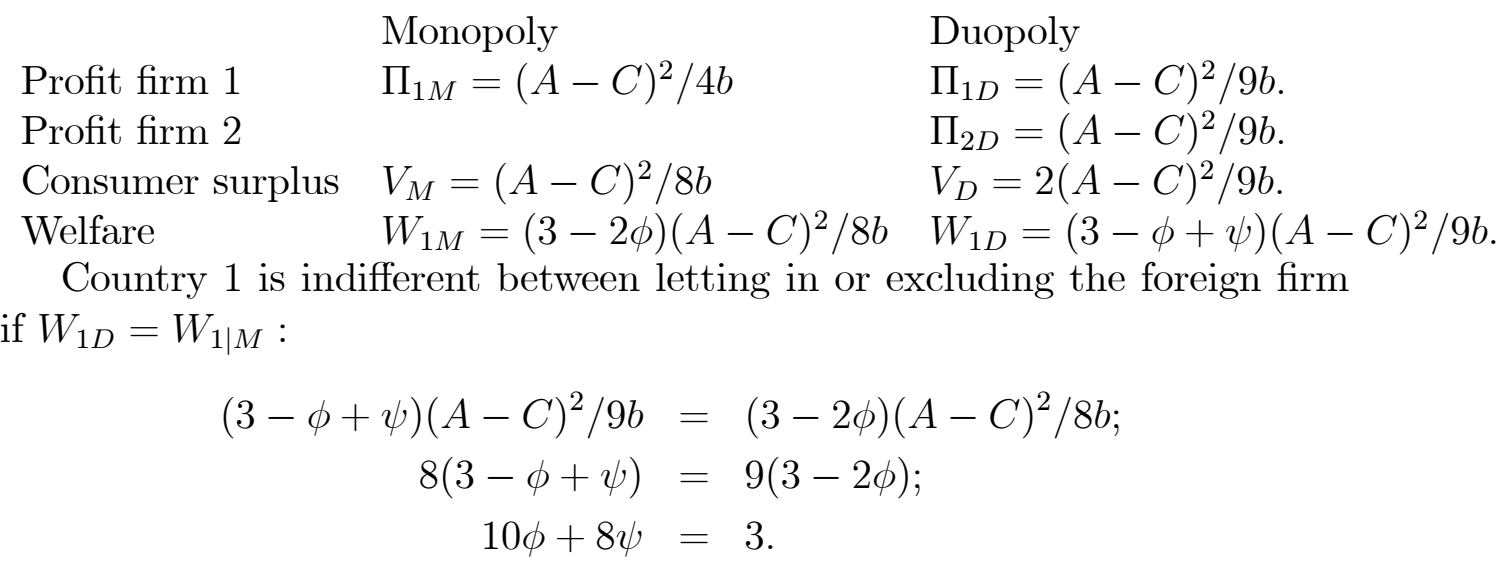

\section{References}

\section{References}

ANDERSON, J.E. AND E.VAN WINCOOP [2003]: 'Gravity with Gravitas: a Solution to the Border Puzzle.' American Economic Review, March 2003, 93, 170-192.

BANDYOPADHYAY, S. [1997]: 'Demand Elasticities, Asymmetry and Strategic Trade Policy'. Journal of International Economics, 42, 167-177.

BERTAUT, C.C., W.L.GRIEVER and R.W.TRYON [2006]: 'Understanding U.S. Cross-Border Securities Data', Federal Reserve Bulletin, May 2006, A59-A75.

BRANDER, J.A. [1981]: 'Intra-industry trade in identical products', Journal of International Economics, 11, 1-14.

BRANDER, J.A. [1995]: 'Strategic Trade Policy'. NBER Working Paper 5020, reprinted in GM Grossman \& K. Rogoff

(ed.) Handbook of International Economics, Elsevier.

BRANDER, J. AND B. SPENCER [1985]: 'Export Subsidies and Market Share Rivalry', Journal of International Economics 18, 83-100. 
DEVEREUX, M.P., R. GRIFFITH AND A. KLEMM [2002] 'Corporate Income Tax Reforms and International Tax Competition', Economic Policy, $35,451-495$.

DICK, A.R. [1993]: 'Strategic trade policy and welfare: the empirical consequences of cross-ownership'. Journal of International Economics 35, 227249.

EATON, J. AND G.GROSSMAN [1986]: 'Optimal Trade and Industrial Policy under Oligopoly', Quarterly Journal of Economics, 101, 383-406.

EDWARDS, T.HUW AND D.GROS [2006]: 'Economic 'Patriotism' and its Inconsistencies', CEI Annual Report (In Italian).

EDWARDS, T.HUW [2007]: 'Horizontal regulatory protection: its appeal and limitations in a linear, Cournot duopoly', Loughborough Economics Discussion Paper WP2007-05 on REPEC.

GROS, D. [2006]: 'Economic 'patriotism': Protecting national champions or competing to attract FDI?' CEPS commentary, http://www.ceps.be/Article.php?article_id=517.

ISHIKAWA, J., Y.SUGITA AND L.ZHAO [2007]: 'Commercial Policy under Cross-Border Ownership and Control'. Mimeo, Hitotsubashi University.

LEE, S. [1990]: 'International Equity Markets and Trade Policy'. Journal of International Economics 29, 173-184.

MASKUS, K.E. AND J.S.WILSON, eds [2001]: 'Quantifying the Impact of Technical Barriers to Trade.' Michigan University Press. Chs 1 and 2 by the editors.

NEARY, J.P. [1994]: 'Cost asymmetries in international subsidy games: should governments help winners or losers?'. Journal of International Economics 37, 197-218.

PAVCNIK, N. [2002]: 'Trade Disputes in the Commercial Aircraft Industry', World Economy, 25(5), 733-751, May 2002.

U.S.DEPARTMENT OF COMMERCE [1990]: 'Foreign Direct Investment in the United States: Balance of payments and direct investment position estimates, 1980-86'. Government Printing Office, Washington D.C.. 
VERON, P. [2006]: 'Farewell, National Champions', Breugel Policy Brief, http://www.bruegel.org/doc_pdf_419

T.Huw Edwards

Department of Economics

Loughborough University

Epinal Way

Loughborough

United Kingdom

E-mail: T.H.Edwards@lboro.ac.uk 